Volume 8

Issue 1 March

Article 2

March 1981

\title{
Humanism and Social Work Paradoxes, Problems, and Promises
}

Norman Goroff

University of Connecticut

Follow this and additional works at: https://scholarworks.wmich.edu/jssw

Part of the Social Work Commons, and the Theory, Knowledge and Science Commons

\section{Recommended Citation}

Goroff, Norman (1981) "Humanism and Social Work Paradoxes, Problems, and Promises," The Journal of Sociology \& Social Welfare: Vol. 8 : Iss. 1 , Article 2.

Available at: https://scholarworks.wmich.edu/jssw/vol8/iss1/2

This Article is brought to you by the Western Michigan University School of Social Work. For more information, please contactwmu-scholarworks@wmich.edu.

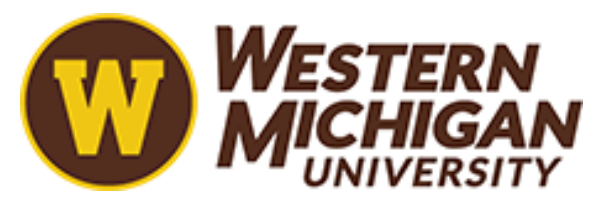


HUMANISM AND SOCIAL WORK

PARADOXES, PROBLEMS, AND PROMISES

\author{
by \\ Norman Goroff \\ The University of Connecticut \\ School of Social Work \\ West Hartford, Conn. 06117
}

\begin{abstract}
Although social work is viewed as a human service profession, with the implicit assumption that it is humanistically oriented, an examination of some of the theoretical orientations, practice settings and practice methodology will reveal a number of paradoxes, problems, and potential promises. I do not claim to provide more than a sampling, to provide a more exhaustive analysis would require considerably more time than is available.
\end{abstract}

There are many definitions of humanism. I am interested in a society in which each individual human being is seen as a person with inherent dignity and worth and not as an object with utility. I am interested in a society in which relationships among human beings are non-exploitive, cooperative, and equalitarian, (Gil, 1976). I am interested in a society in which the resources created by human beings through their labor is distributed so as to provide each person with the goods and services to meet his/her needs without denying others theirs. I am interested and concerned that each individual have equal opportunities to develop to his/her fullest human potential. My yardstick for measuring any social policy is related to how does the policy and program relate to these concerns. Will this program create equal opportunities for each individual to develop to his/her fullest potential? Does this policy and program help distribute the product of human labor to meet human needs? Does the policy and program recognize the inherent dignity and worth of each individual or does it continue to view the human being as an object with or without utility. Does the policy or program facilitate the establishment of non-exploitive equalitarian cooperative relationships or does it continue the hierarchial competitive, exploitive relationships and structures?

Within this framework, I should like to begin to discuss some of the paradoxes between humanism and social work. It is obvious that my definition of humanism involves a political orientation. This is partly due to the fact that I place stress on the creation of a society in which the values professed by social work can be realized. Nuch of social work practice focuses on the individual and the family without sufficient attention to the socio-economic foundation of our society and the consequences for all human beings. Social work practice is frequently described as apolitical.

It is in failing to recognize that all social work practice is political practice that we can see some of the paradoxes between humanism and social work. All social work practice occurs within 
social institutions. These institutions, whether publicly financed or privately financed through United Ways, are designed to provide services so that the existing social arrangements and social order may be malntained, (Piven and Cloward, 1971; Goroff 1973; Mandell, 1973).

Social workers who perform their services within these institutional structures are performing a political act, whether that act is arrived at attempting to change the institutional arrangements or to maintain and strengthen them, (Galper 1975). To the degree that our social institutions are based on promises other than those defined as humanistic, the social worker is placed in a paradoxical situation i.e. how to practice as a human in a social institution that is non-humanistic. The recognition that social work practice is political activity holds one of the potential promises. I will elaborate upon this point later in the paper.

Vertical relationship, ie. hierarchially structured relationships are inherently oppressive in as much as it places the subordinate individual in a position in which his/her needs, wants and desires are not the motivating factor involved in the interaction. Many relationshlps established between the social worker and the individual seeking help within this institutional structure reflect what Mills called, "the vocabulary of motives." The social expectations for the social worker and the "client" in these settings are part of the culture. Frequently there is an ideology of paternalism and non-reciprocity permeating the cultures of the bureaucratic structured social service institutions. The inequity in power and authority reflected in the vertical relationships (Freire, 1973) can be conceptualized as a political relationship parading as a professional relationship.

One of the consequences of the verticle relationship is for the social worker to become an agent of social control for maintaining the status quo and conformity. Social workers became "soft-cops." This relationship is contrary to the egalitarian cooperatives and non-exploitive relationship inherent in my definition of social worker. There is an alternative relationship described by Friere as a horlzontal relationship. He describes this relationship as one in which there is a commitment to equality, to the abolition of privileges, and to non-elitist forms of leadership wherein special qualifications may be exercised, but are not elaborated upon later in the paper.

Some of the theoretical knowledge that social workers utilize in their work presents some paradoxes for the humanist social worker. Social workers have used different psychological frameworks in attempting to understand the human condition. Rarely, however, have the political implications of the various psychological theories been examined. For exampie, psychological theories which posit a natural order of developmental stages which individuals must pass through results in diagnosing problems as being due to the inability 
of the individual to successfully negotiate a state of development (Sternberg, 1977). The consequences of this framework is to place the genesis of the problem within the individual, ignoring how the social order is impacting the person. It is true that the pain resulting from the problem the individual is experiencing is within the individual, however the cause is frequently in the social arrangement we have perpetuated. The consequence is to focus on the individual rather than on the socio-economic arrangements.

Sociological concepts become psychologicalized with the political consequence of shifting the focus from the social arrangements to the individual. The most glaring example of this is in the concept of alienation. One can point to Seeman (1959) and his definition of alienation as a feeling of powerlessness, a feeling of meaninglessness, a feeling of normlessness, a feeling of isolation, a feeling of self-estrangement as a clear illustration of a concept which originated in an analysis of the socio-economic structure and relationship to that property of the individual.

There are many psychological and sociological theories which are premised on the "individual deficit model." To the degree that social workers utilize these frameworks as a basis for trying to understand the human condition, they find themselves in situations in which they impose their world view upon those seeking their help. The paradox here for the social worker who is trying to be a humanist is that the individual becomes an "object to be studied and diagnosed" for his/her deficiencies rather than an individual to be understood.

As social work became increasingly "professional" with appropriate professional organizations, graduate schools, state licensing, there has been an accompanying increase in mystitication. An important aspect of trying to lay claim to an area of practice as one's exclusive domain i.e. become professional, is to develop an expertise. The "expertise" in social work as in most "professions" is such as to require a considerable degree of mystification. Mystification is a major component of dehumanization (Lee, 1976). This is accomplished by taking everyday human experiences, abstracting and reifying them. Again, in an attempt to legitimate the claim of social workers that we are a profession we have created a paradox for the humanistic social worker. We have mystified ourselves.

Many linguists have long recognized the relationship of language, thought and activities. The fact that words connote status differentials, authority relations and differential access to resources have not been sufficiently stressed in many of the helping professions including social work. Since the most common stance is to view social work as a benevolent helping profession, the use of language is not necessarily seen as defining political realities, but rather the dynamics of the "helping process." One of the major functions of any political term is to marshall public 
support or opposition, (Edelman, 1974). Social workers rarely try to impose their will on others; it is the other that is "resisting help." Social workers are not punitive people, we merely set limits for people. We do not deny people what they want, we refuse to reinforce or reward "demanding behavior." We use language to distort reality and thus create additional paradoxes for the humanist social worker.

Probably one of the more serious paradoxes for the humanistic social worker is the use of social science theories to impose meaning on the behavior of people rather than finding out how the people are defining their world and what they are trying to achieve. The need to understand the empirical world of the actor in order to understand the actor was stressed by Blumer (1969) and others. Yet, in the hope of gaining legitimacy in the academic world, social work has become a scientistic profession rather than a scientific profession.

The utilization of theoretical constructs as criteria for judging the rationality or normality of human behavior seems like a reversal of what ought to be. There is the assumption that if the individual's behavior does not confrom with the theoretical construct, then there is something wrong with the person, not the theory.

It is possible to continue to illustrate the paradoxes facing a humanistic social worker because of how social work services are delivered, how social workers utilize theories, the conservative ideological implications of many of the psychological and sociological theories (Zettlin, 1968) borrowed from these disciplines and the failure to recognize social work activities as political activities.

The problems faced by the humanistic social worker can frequently be traced to the nature and structure of the social service institutions. Most institutions are hierarchically organized, i.e. have verticle patterns of relationships. The bureaucratic controls exercised over the social worker create situations which results in conflict between "professional autonony" and organizational restraints. Most of the organizational restraints originate from the requirement of the organization to maintain itself rather than providing services to those who need it.

The conflict between the needs of the people for service and the organization to maintain itself may place the social worker in the r.j.cdle. Most of these conflicts are between parties with unequal power. The social worker who tries to maintain a neutral stance is actually siding with the more powerful institution for neutrality in conflictual situations involving parties with unequal power is to support the more powerful party.

When the social worker sides with the people seeking help, 
he/she is frequently seen by others as a troublemaker not team player, etc. because he/she is in conflict with the others. The person is in danger of losing his/her job or else receiving a poor reference. A student social worker challenged the staff decision and action in the case of a ten year old boy with the result that the situation deteriorated to the point where we removed him from the setting. He was described as "impulsive" not following "procedures," "unable to handle authority" when all he did was to question whether the decision is really meeting the needs of the child or of the institution.

Problems may arise for the humanistically oriented social worker as a consequence of being involved with graduate social work education. A study of two hundred students at a graduate school of social work indicated that bureaucratically oriented people upon entering the school graduated school with the same orientation. All the people who entered individualistically oriented i.e., concerned with the individual, over eighty percent graduated with a bureaucratic orientation. The remaining students were seen by faculty and students as "different." There have been studies which tried to examine the impact of graduate education for social work on students' values. Admittedly there is little correlation between the answers people give on paper and tests and their actions in the actual situations. Nevertheless, there is sufficient data to raise questions whether social work education supports humanistic orientations or whether it educates bureaucrats.

Another problem is found in the relativistic aspects of humanism vis-a-vis an oppressive situation. When one thinks that compared to the oppressive conditions prevailing what " $I$ do is better and therefore humanistic" without truly understanding that like pregnancy there is no such condition as a "little oppression." Recently, a social worker published a paper describing "A Humanistic Approach to Helping Underachieving Students," (Zeff, 1977) in which she described how she helped a school develop an alternative approach to suspension and "pushing out" deviant students. She notes "The experientially based, humanistic group tutoring program, established the following goals for the students:

1. More regular school attendance.

2. Decrease in maladaptive behavior.

3. Improved self-concept.

4. Feeling of worth in a climate of acceptance.

5. Preparation to apply for jobs if they dropped out of school.

6. Acceptance at trade school if and when appropriate if such a plan was desired by the student."

In my view, establishing goals for others is not humanistic. 
I don't know whether it is more or less humane considering the total situation in the school for the students to attend school regularly. Without fully understanding how the world looks to the students, how they define it and what they want to achieve, it is difficult to accept the definition that their behavior was maladaptive. Their behavior may have caused others to feel their authority was being challenged, but except for causing the students grief, it is not a question of maladaptive but of non-conforming behavior.

The problem highlighted by this article is in how the term "humanistic" was used. My analysis of the article is that the author described a less oppressive situation for fifteen students, but still within an oppressive situation. In comparison to the general practice, what she did should be applauded, but not because it is "humanistic" but because she tried within her limitations to help create a more tolerable situation for fifteen human beings. She had little impact on the school as an institution. There was no continuance of the program after the one time it occurred.

The promise for a humanistic social work is in the recognition that social work practice is political practice. In this framework one can no longer parade as an apolitical or political neutral social worker. I an not referring to the fact that our activity as social workers and sociologist either maintain the current social arrangements and inequitable distribution of resources and the resultant unequal life chanced for people or seeks to help deter these arrangements.

The pronise for a humanistic social work practice lies in the recognition by social workers that we are either oppressors or are being oppressed. It is also necessary to recognize that we can be oppressed while oppressing others. This involves a change in consciousness to become more critical of the socio-economic foundation of our society and the cultural belief system, (Gil, 1977). The need to recognize that "the ruling ideas are the ideas of the ruling class." The ruling ideas are nothing more than the ideal expression of the dominant material relationships grasped as ideas, hence of the relationships which make the one class the ruling one and therefore the ideas of its domination, (Easton and Guddat, 1967).

The promise for a humanistic social work practice lies in the recognition that all social theories make certain assumptions about the nature of the human being, the nature of the collectivity and the relationship between the individual and the collectivity, (Goroff, 1973). There are political consequences which result from these theories that are important for social workers to analyze with critical insight. 
The promise for a humanistic social work practice lies in the willingness of social workers to give up our arrogance which allows us to justify our planning or establishing goals for others and to recognize that we are like the people, seeking self-actualization which can only be achleved in a society that is egalitarlan cooperative and non-exploited. Only in such a society can all human beings achieve self-actualization.

Admittedly, I have been describing the need for a revolution. A revolution is a process, i.e., a series of events over time and not a single event. The promise for a humanistic social work practice will be fulfilled as we become engaged in the process of creating a fust and humane social order. The social order that we are currently participating in and therefore helping to create is not designed to meet the criteria.

We must recognize that we are part of a society that is in a state of "massification." As Friere (1973) states "For men to overcome their state of massification, they must be enabled to reflect about that very condition. But since authentic reflection cannot exist apart from action, men must also act to transform the concrete reality which has determined their massification. This is what we must do! 


\section{REFERENCES}

Blau, Peter and Scott, Richard W.

1962 Organizations, San Francisco, California, Chandler Publishing Company.

Blumer, Herbert

1969 Symbolic Interactionism Perspective and Method, Englewood Cliffs, New Jersey, Prentice-Ha11, Inc.

Easton, Loyd and Guddlt, Kurt $H$.

1967 Writings of the Young Marx on Philosophy and Society, Garden City, New York, Doubleday and Company Inc.

Edelman, Murray

1974 "The Political Language of the Helping Professions," Politics and Society.

Freire, Paulo

1973 Education for Critical Consciousness, New York, Seabury Press.

Galper, Jeffry

1975 The Politics of Social Service, Englewood Cliffs, New Jersey Prentice-Ha11, Inc.

Gil, David G.

1976 "Resolving Issues of Social Provision," in The Challenge of Social Equality, Cambridge, Mass, Schenkman Publishing Company, Inc.

Gil, David G.

1977 "Overcoming Cultural Impediments to Human Survival," Humanity and Society, Vol. 1, No. 1, Summer.

Goroff, Norman N.

1973 "Ideology, Sociological Theory and Public Policy," Journal of Sociology and Social Welfare, Vol. 1, No. 1.

Goroff, Norman N.

1974 "Social Welfare As Coercive Social Contro1," Journal of Sociology and Social Welfare, Vo1. 2, No. 1.

Lee, Alfred McClung

1976 "Humanism As Demystification," Journal of Sociology and Social Welfare, Vol. 3, No. 3, January.

Mande11, Betty Reid

1975 Welfare in America, Englewood Cliffs, New Jersey, Prentice-Hall, Inc. 
Piven, Frances and Cloward, Richard

1971 Regulating the Poor, New York Random House.

Seeman, Melvin

1959 "On the Meaning of Alienation," American Sociological Review, Vol. 24, December.

Steinberg, David Joel

1977 Radical Sociology - A Critical Introduction to American Behavioral Science, Hicksville, New York, Exposition Press.

Zeitlin, Irving

1968 Ideology and the Development of Sociological Theory, Englewood Cliffs, New Jersey, Prentice-Hall, Inc.

Zeff, Shirley B.

1977 "A Humanistic Approach To Helping Underachieving Students," Social Casework, Vol. 58, No. 6, June. 